\title{
Four flavonoid glycosides from the pulps of Elaeagnus angustifolia and their antioxidant activities
}

\author{
Ya Wang, Tao Guo*, Jia-yin Li, Shang-zhen Zhou, \\ Ping Zhao \\ School of Life and Engineering, Lanzhou University of \\ Technology. Lanzhou, China \\ gt010010@sina.com
}

\begin{abstract}
Four flavonoid glycosides were isolated from the pulps of Elaeagnus angustifolia and identified as Quercetin

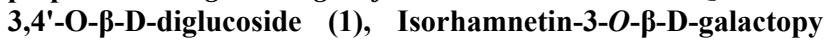
-ranoside (2), Quercetin 3-O- $\beta$-D-Galactopyranoside- 4'-O$\beta$-D-glucopyranoside (3) and Isorhamnetin 3-O-B-D-Galacto -pyranoside-4'-O- $\beta$-D-glucopyranoside (4). Among which, the compounds 1,3 and 4 were isolated for the first time from this plant. The antioxidant activities of the four compounds were evaluated by measuring their reducing power and ability to scavenge the ABTS radical, DPPH radical and to inhibit superoxide anions. The results indicated that theses compounds exhibited antioxidant activities with a dose-dependent manner in all tested models, and had some structure-activity relationships. The order of potential antioxidant capacity was as follows: $1>3>2>4$. Considering related reports, the flavonoid might be responsible for antioxidant activity of pulps of $E$. angustifolia.
\end{abstract}

Keywords-Elaeagnus angustifolia; antioxidant activity; flavonoid

\section{INTRODUCTION}

The genus Elaeagnus (Araliaceae) consists of more than 80 species, which are mainly distributed in Asia and Europe, partly in the Northern America. There are approximate 55 species in China [1]. Elaeagnus angustifolia L., a deciduous arbor or small arbor (5-10m high), is widely distributed in northwest China such as Xinjiang, Gansu, and other provinces. Flower, fruit, leaf and bark of the plant has been used in Traditional Chinese Medicine for the treatment of asthenia of the spleen and stomach, dyspepsia, enteritis, diarrhea and cough with yellow sputum [2]. The $E$. angustifolia fruit is an autumn fruit which is generally consumed dried, and is rich in many effective components. Modern pharmacological studies have found that $E$. angustifolia fruit has anti-fatigue [3], anti-inflammatory [4], antioxidant activities [5] and other health functions. Up to now, nine flavonoids including $(+)$-catechin, (-)-epicatechin, $(+)$-gallocatechin, (-)-epigallocatechin, kaempferol, quercetin, luteolin, isorhamnetin and isorhamnetin-3-O- $\beta$ D--galactopyranoside have already been isolated and identified from this plant $[6,7]$.

Flavonoids, a group of low molecular weight polyphenolic substances including flavone, flavonols, isoflavone, flavanol, flavanone, anthocyanin and proanthocyanidin, widely exist in fruits, vegetables . In fact, these flavonoid compounds have attracted the attention of food and medical scientists because of their strong in vitro

\author{
Ming-Tao Fan \\ Northwest Agriculture Forestry University, College of Food \\ Science and Engineering. Yangling, China
}

and in vivo antioxidant activities and their ability to scavenge free radicals, break radical chain reaction and chelate metals[8]. In this study, four flavonoid glycosides were isolated from the pulps of E. angustifolia and identified according to their NMR and mass spectra. Moreover, their antioxidant activities were evaluated and compared.

\section{MATERIAL AND CHEMICALS}

\section{A. Chemicals}

DPPH and ABTS were purchased from Sigma. All other reagents and solvents used in this study were of analytical grade.

\section{B. Plant material}

Mature fruits of E. angustifolia were collected in July of 2008 from Gulang town, Gansu in China $\left(37^{\circ} \mathrm{N}\right.$ and $\left.102^{\circ} \mathrm{E}\right)$. The plant was identified by Prof. Sheng-Li Pan. A voucher specimen SM/WY/08/02 was deposited in our laboratory for future reference.

\section{Extraction and isolation}

Air-dried fruit pulps of E. angustifolia $(1.5 \mathrm{~kg})$ were percolated with $50 \% \mathrm{EtOH}$, The solvent was evaporated under reduced pressure to produce the ethanol extract (720 g). The extract was subjected to macroporous resin NKA-9 column chromatography and eluted with an EtOH- $\mathrm{H}_{2} \mathrm{O}$ gradient. The solution that was eluted with $70 \%$ ethanol was evaporated to dryness under vacuum to afford a residue (59 g). The residue was chromatographed on silica gel with a $\mathrm{CH}_{3} \mathrm{Cl}_{3}-\mathrm{MeOH}$ gradient to provide eight fractions. The fraction eluted with $\mathrm{CH}_{3} \mathrm{Cl}_{3}-\mathrm{MeOH}$ (4:1) yield compound 1 (15 mg).

The solution that was eluted with $50 \%$ ethanol was evaporated to dryness under vacuum to afford a residue (59 g). The residue was eluted with ethyl acetate- $\mathrm{MeOH}$. The fraction eluted with $\mathrm{CH}_{3} \mathrm{Cl}_{3}-\mathrm{MeOH}$ (8:1) afforded compound 2 (7 $\mathrm{mg})$. The fraction eluted with $\mathrm{CH}_{3} \mathrm{Cl}_{3}-\mathrm{MeOH}(5: 1)$ was subjected to preparative HPLC using the solvent system $\mathrm{MeOH}-\mathrm{H}_{2} \mathrm{O}(\mathrm{v} / \mathrm{v}=35: 65)$ to afford componds $3(5 \mathrm{mg})$ and $4(6 \mathrm{mg})$.

Quercetin 3,4'-O- $\beta$-D-diglucoside (1). Brown powder; ESI-MS $m / z: 627.1[\mathrm{M}+\mathrm{H}]^{+}$; ${ }^{1} \mathrm{HNMR}\left(400 \mathrm{MHz}, \mathrm{CD}_{3} \mathrm{OD}\right)$ $\delta: 7.71[1 \mathrm{H}, \mathrm{dd}, J=8.6 / 2.2 \mathrm{~Hz}, \mathrm{H}-6 '], 7.52[1 \mathrm{H}, \mathrm{d}, J=2.2 \mathrm{~Hz}$, H-2'], 6.86 [1H, d, $\left.J=8.7 \mathrm{~Hz}, \mathrm{H}-5^{\prime}\right], 6.37$ [1H, d, $J=1.6 \mathrm{~Hz}$, $\mathrm{H}-8], 6.18$ [1H, d, $J=1.7 \mathrm{~Hz}, \mathrm{H}-6], 5.15$ [ $1 \mathrm{H}, \mathrm{d}, J=7.3 \mathrm{~Hz}$, $\mathrm{H}-1 "], 4.73$ [ $1 \mathrm{H}, \mathrm{d}, J=7.1 \mathrm{~Hz}, \mathrm{H}-1 " '] .{ }^{13} \mathrm{C} \mathrm{NMR}(100 \mathrm{MHz}$, 
$\left.\mathrm{CD}_{3} \mathrm{OD}\right)$ data, see Table 1 .

Isorhamnetin-3-O- $\beta$-D-galactopyranoside (2). Yellow powder; ESI-MS $m / z: \quad 479.1[\mathrm{M}+\mathrm{H}]^{+}, \quad 477.5[\mathrm{M}-\mathrm{H}]^{-}$; ${ }^{1} \mathrm{H}-\mathrm{NMR}\left(\mathrm{CD}_{3} \mathrm{OD}, 400 \mathrm{MHz}\right): \delta 8.03\left(1 \mathrm{H}, \mathrm{d}, J=2.0, \mathrm{H}-2^{\prime}\right)$, $7.57(1 \mathrm{H}, \mathrm{dd}, J=8.4 / 2.0 \mathrm{~Hz}, \mathrm{H}-6 '), 6.89(1 \mathrm{H}, \mathrm{d}, J=8.8 \mathrm{~Hz}$, $\left.\mathrm{H}^{-5}\right), 6.40(1 \mathrm{H}, \mathrm{d}, J=2.4, \mathrm{H}-8), 6.20(1 \mathrm{H}, \mathrm{d}, J=2.4, \mathrm{H}-6)$, 5.34(1H, d, $J=8 \mathrm{~Hz}, \mathrm{H}-1 "), 3.94\left(1 \mathrm{H}, \mathrm{s}, \mathrm{OCH}_{3}\right) .{ }^{13} \mathrm{C}$ NMR(100MHz, $\left.\mathrm{CD}_{3} \mathrm{OD}\right)$ data, see Table 1.

Quercetin 3-O- $\beta$-D-Galactopyranoside-4'-O- $\beta$-D-glu -copyranoside (3). Yellow powder; ESI-MS m/z: 625.4 $[\mathrm{M}-\mathrm{H}]^{-} ;{ }^{1} \mathrm{H}-\mathrm{NMR}\left(\mathrm{CD}_{3} \mathrm{OD}, 400 \mathrm{MHz}\right): \delta: 7.67 \quad[1 \mathrm{H}, \mathrm{dd}$, $J=8.7 / 2.1 \mathrm{~Hz}, \mathrm{H}-6 '], 7.63$ [1H, d, $J=2.1 \mathrm{~Hz}, \mathrm{H}-2 '], 7.18$ [ 1H, d, $\left.J=8.7 \mathrm{~Hz}, \mathrm{H}-5^{\prime}\right], 6.44[1 \mathrm{H}, \mathrm{d}, J=2.0, \mathrm{H}-8], 6.21[1 \mathrm{H}, \mathrm{d}$, $J=2.0, \mathrm{H}-6], 5.40[1 \mathrm{H}, \mathrm{d}, J=7.7 \mathrm{~Hz}, \mathrm{H}-1 "], 4.76[1 \mathrm{H}, \mathrm{d}$, $J=7.1 \mathrm{~Hz}, \mathrm{H}-1$ "']. ${ }^{13} \mathrm{C} \mathrm{NMR}\left(100 \mathrm{MHz}, \mathrm{CD}_{3} \mathrm{OD}\right)$ data, see Table 1.

\begin{tabular}{|c|c|c|c|c|c|}
\hline & $\mathrm{c}$ & 1 & 2 & 3 & 4 \\
\hline Flavonol & $\begin{array}{c}2 \\
3 \\
4 \\
5 \\
6 \\
7 \\
8 \\
9 \\
10 \\
1^{\prime} \\
2^{\prime} \\
3^{\prime} \\
4^{\prime} \\
5^{\prime} \\
6^{\prime} \\
-\mathrm{OMe}\end{array}$ & $\begin{array}{c}158.4 \\
136.0 \\
180.1 \\
162.0 \\
100.9 \\
165.3 \\
96.8 \\
160.0 \\
106.5 \\
124.9 \\
118.9 \\
145.8 \\
149.7 \\
117.7 \\
123.9\end{array}$ & $\begin{array}{c}158.6 \\
135.4 \\
179.6 \\
163.1 \\
99.8 \\
165.9 \\
94.6 \\
158.4 \\
105.7 \\
123.0 \\
114.6 \\
148.4 \\
150.8 \\
115.9 \\
123.5 \\
56.9\end{array}$ & $\begin{array}{c}158.5 \\
135.1 \\
179.9 \\
163.1 \\
99.8 \\
165.9 \\
94.7 \\
158.8 \\
105.0 \\
123.0 \\
116.2 \\
145.9 \\
148.2 \\
112.0 \\
117.8\end{array}$ & $\begin{array}{c}158.7 \\
134.8 \\
179.5 \\
163.0 \\
99.8 \\
165.9 \\
94.6 \\
158.4 \\
105.7 \\
123.0 \\
114.3 \\
148.4 \\
150.8 \\
115.0 \\
123.5 \\
57.1\end{array}$ \\
\hline$\underset{\mathrm{C}-3}{\text { Sugar at }}$ & $\begin{array}{l}1^{\prime \prime} \\
2^{\prime \prime} \\
3^{\prime \prime} \\
4^{\prime \prime} \\
5^{\prime \prime} \\
6 "\end{array}$ & $\begin{array}{c}104.5 \\
75.9 \\
78.0 \\
71.9 \\
79.7 \\
63.1\end{array}$ & $\begin{array}{c}104.4 \\
73.1 \\
75.0 \\
70.0 \\
77.2 \\
62.2\end{array}$ & $\begin{array}{c}101.9 \\
74.9 \\
75.4 \\
70.0 \\
77.9 \\
62.3\end{array}$ & $\begin{array}{c}104.2 \\
74.7 \\
75.2 \\
69.4 \\
77.7 \\
62.4\end{array}$ \\
\hline$\underset{\mathrm{C}-4^{\prime}}{\text { Sugar at }}$ & $\begin{array}{l}1 " ' \\
2^{\prime \prime \prime} \\
3^{\prime \prime \prime} \\
4 " ' \\
5^{\prime \prime \prime} \\
6 " '\end{array}$ & $\begin{array}{c}102.8 \\
75.4 \\
77.2 \\
70.9 \\
78.4 \\
62.7\end{array}$ & & $\begin{array}{c}101.7 \\
77.0 \\
78.1 \\
71.0 \\
80.7 \\
61.9\end{array}$ & $\begin{array}{c}101.3 \\
77.0 \\
78.1 \\
71.1 \\
79.7 \\
62.1\end{array}$ \\
\hline
\end{tabular}

Isorhamnetin 3-O- $\beta$-D-Galactopyranoside-4'-O- $\beta$-Dglucopyranoside (4). Yellow powder; ESI-MS $\mathrm{m} / \mathrm{z}$ : 641.1 $[\mathrm{M}+\mathrm{H}]^{+} ;{ }^{1} \mathrm{H}-\mathrm{NMR}\left(\mathrm{CD}_{3} \mathrm{OD}, 400 \mathrm{MHz}\right): \delta 7.93(1 \mathrm{H}, \mathrm{d}, \mathrm{J}=2.4$ Hz, H-2'), 7.62(1H, dd, $\left.J=8.4 / 2.4 \mathrm{~Hz}, \mathrm{H}-6{ }^{\prime}\right), 6.90$ (1H, $J=8.4$ $\left.\mathrm{Hz}, \mathrm{H}-5^{\prime}\right), 6.39(1 \mathrm{H}, \mathrm{d}, J=2.0, \mathrm{H}-8), 6.18(1 \mathrm{H}, \mathrm{d}, J=2.0, \mathrm{H}-6)$, $5.53\left(1 \mathrm{H}, \mathrm{d}, J=7.6 \mathrm{~Hz}, \mathrm{H}-1^{\prime \prime}\right), 4.77\left(1 \mathrm{H}, \mathrm{d}, J=7.2, \mathrm{H}-1 "{ }^{\prime \prime}\right) .{ }^{13} \mathrm{C}$ NMR(100MHz, $\left.\mathrm{CD}_{3} \mathrm{OD}\right)$ data, see Table 1.

\section{Antioxidant assays}

ABTS radical scavenging activity: The method as described previously [9] was used to determine the antioxidant capacity of obtained compounds. $\mathrm{ABTS}^{+}$stock solution was prepared by reacting $5 \mathrm{ml}$ of $7 \mathrm{mM}$ ABTS water solution with $88 \mu \mathrm{L}$ of $140 \mathrm{mM}$ potassium persulphate, and the mixture was away from light at room temperature for $12-16 \mathrm{~h}$ before use. To this end, the $\mathrm{ABTS}^{+}$stock solution was diluted with $80 \%$ methanol to the absorbance of $0.70 \pm$
0.02 at $734 \mathrm{~nm}$. For the spectrophotometric assay, $3.8 \mathrm{~mL}$ of the $\mathrm{ABTS}^{+}$working solution and $0.2 \mathrm{~mL}$ of the sample solution were mixed and absorbance was measured immediately after $6 \mathrm{~min}$. The percentage inhibition was calculated with the foll-owing equation: inhibition $(\%)=$ $\left(\mathrm{A}_{\text {control734 }}-\mathrm{A}_{\text {sample734 }}\right) / \mathrm{A}_{\text {control734 }} \times 100$, in which $\mathrm{IC}_{50}$ is the concentration of half-inhibition.

DPPH radical scavenging activity: Assay for DPPH free radical scavenging capacity was based on the scavenging activity of stable DPPH free radicals [10]. The reaction mixtures containing $2.5 \mathrm{~mL}$ of test samples solution and DPPH $(0.025 \mathrm{mg} / \mathrm{ml})$ were incubated for $30 \mathrm{~min}$. Following that, the absorbance at $517 \mathrm{~nm}$ was measured and the inhibition (\%) of DPPH radical formation was calculated with the following equation: inhibition $(\%)=$ $\left(\mathrm{A}_{\text {control517 }}-\mathrm{A}_{\text {sample517 }}\right) / A_{\text {control517 }} \times 100$, in which $\mathrm{IC}_{50}$ is the concentration of half-inhibition.

Superoxide anion radical scavenging activity: The superoxide anion radical scavenging activity was performed using the previously reported method developed by Zhang, et al., 2011[11]. A pyrogallol solution $(3 \mathrm{mM})$ was added to a tube containing a sample that had been dissolved in Tris-HCl-EDTA buffer (0.1 M, pH 8.0). The UV absorbance was in triplicate measured at $320 \mathrm{~nm}$. The antioxidant activity was determined as the percentage of inhibited pyrogallol autoxidation and was calculated as follows: $\left(\mathrm{A}_{\text {control320 }}-\mathrm{A}_{\text {sample320 }}\right) / \mathrm{A}_{\text {control320 }} \times 100$, in which $\mathrm{IC}_{50}$ is the concentration of half-inhibition.

Reducing power: The reducing power was determined by the method described previously[12] with little modification. The samples with different concentrations were mixed with sodium phosphate buffer $(2.5 \mathrm{~mL}, 0.2 \mathrm{M}, \mathrm{pH}$ 6.6) and potassium ferricyanide $\left[\mathrm{K}_{3} \mathrm{Fe}(\mathrm{CN})_{6}\right](2.5 \mathrm{~mL}, 1 \%)$. The mixture was incubated at $50^{\circ} \mathrm{C}$ for $20 \mathrm{~min}$. After incubation, trichloroacetic acid $(2.5 \mathrm{~mL}, 10 \%)$ was added to the reaction mixture, which was subsequently centrifuged at $6000 \mathrm{rpm}$ for $10 \mathrm{~min}$. The upper layer solution $(2.5 \mathrm{~mL})$ was mixed with distilled water $(2.5 \mathrm{~mL})$ and ferric chloride solution $(0.1 \%, 0.5 \mathrm{~mL})$, and its absorbance was measured at $700 \mathrm{~nm}$. Increased absorbance of the reaction mixture indicated increased reducing power.

\section{E. Statistical analysis}

Data were expressed as the mean values \pm standard deviation (SD) for each measurement. All analysis was performed with SPSS 13.0.

\section{RESULTS AND DISCUSSION}

Our previous studies revealed that the $50 \%$ ethanol extract of the pulps of E. angustifolia had antioxidant activity. These fractions eluted with $70 \%, 50 \%$ and $30 \%$ when the ethanol extract was subjected to macroporous resin NKA-9 column chromatography, showed significantly antioxidant effect. In the present study, four compounds from pulp of $E$. angustifolia were isolated, and identified by spectra methods [13-15], as Quercetin 3,4'-O- $\beta$-D-diglucoside (1), Isorhamnetin-3-O- $\beta$-Dgalactopyranoside (2), Quercetin 3-O- $\beta$-D-Galactopyrano -side-4'-O- $\beta$-D-glucopyranoside (3) and Isorhamnetin 
3-O- $\beta$-D-Galactopyranoside-4'-O- $\beta$-D-glucopyranoside (4). Among which, the compounds 1,3 and 4 were isolated for the first time from this plant. In addition, the antioxidant

TABLE 2. THE PERCENTAGE INHIBITION OF ABTS AND DPPH FREE RADICAL, AND THE ABSORBANCE IN REDUCING POWER TEST FROM DIFFERENT CONCENTRATIONS OF COMPOUNDS 1-4 AND VC

\begin{tabular}{|c|c|c|c|c|c|c|}
\hline $\begin{array}{c}\text { Concentration } \\
(\mu \mathrm{g} / \mathrm{mL})\end{array}$ & $\mathrm{vC}$ & 1 & 3 & $\begin{array}{c}\text { Concentration } \\
(\mu \mathrm{g} / \mathrm{mL})\end{array}$ & 2 & 4 \\
\hline \multicolumn{7}{|c|}{ ABTS free radical scavenging test } \\
\hline 20 & $27.19 \pm 0.229$ & $7.31=0.180$ & $14.49 \pm 0.377$ & 20 & $0.95 \pm 0.071$ & $9.22 \pm 0.121$ \\
\hline 40 & $55.45 \pm 0.294$ & $25.89 \pm 0.290$ & $16.92 \pm 0.415$ & 40 & $5.61 \pm 0.211$ & $12.77 \pm 0.289$ \\
\hline 60 & $72.29 \pm 0.191$ & $33.00 \pm 0.382$ & $25.88 \pm 0.272$ & 60 & $13.51 \pm 0.255$ & $18.80 \pm 0.335$ \\
\hline 80 & $99.72=0.042$ & $42.53 \pm 0.334$ & $34.82=0.458$ & 80 & $20.83 \pm 0.275$ & $25.04 \pm 0.185$ \\
\hline 120 & $99.82 \pm 0.031$ & $66.44 \pm 0.315$ & $44.83 \pm 0.385$ & 120 & $32.48 \pm 0.269$ & $30.66 \pm 0.273$ \\
\hline 160 & $99.89=0.035$ & $87.75 \pm 0.446$ & $53.65 \pm 0.383$ & 160 & $48.51=0.285$ & $44.56 \pm 0.248$ \\
\hline \multicolumn{7}{|c|}{ DPPH free radical scavenging test } \\
\hline 0.4 & $10.42=0.161$ & $7.57 \pm 0.337$ & $10.41=0.258$ & 4 & $11.21=0.405$ & $3.35 \pm 0.093$ \\
\hline 0.8 & $27.80=0.335$ & $14.88=0.417$ & $14.97=0.149$ & 8 & $23.98 \pm 0.243$ & $6.33 \pm 0.143$ \\
\hline 1.6 & $53.44 \pm 0.419$ & $30.97 \pm 0.171$ & $21.94 \pm 0.370$ & 16 & $34.65 \pm 0.642$ & $12.06 \pm 0.213$ \\
\hline 2.4 & $85.58=0.432$ & $50.32=1.445$ & $33.48=0.351$ & 24 & $63.77 \pm 1.271$ & $20.77 \pm 0.377$ \\
\hline 3.2 & $87.62 \pm 0.378$ & $64.06 \pm 0.396$ & $41.49 \pm 0.291$ & 32 & $75.17 \pm 0.480$ & $26.09 \pm 0.211$ \\
\hline 4.0 & $90.42=0.354$ & $78.66 \pm 0.704$ & $56.50 \pm 0.391$ & 40 & $88.50 \pm 0.863$ & $32.40 \pm 0.414$ \\
\hline \multicolumn{7}{|c|}{ Reducing power test } \\
\hline 40 & $1.265 \pm 0.019$ & $0.071=0.001$ & $0.050 \pm 0.001$ & 1000 & $0.747 \pm 0.008$ & $0.062 \pm 0.002$ \\
\hline 80 & $1.601 \pm 0.011$ & $0.308 \pm 0.006$ & $0.257 \pm 0.005$ & 1200 & $1.023 \pm 0.009$ & $0.103 \pm 0.004$ \\
\hline 120 & $1.737 \pm 0.031$ & $0.570 \pm 0.008$ & $0.538 \pm 0.006$ & 1400 & $1.232 \pm 0.017$ & $0.127 \pm 0.005$ \\
\hline 160 & $1.801 \pm 0.006$ & $0.913 \pm 0.010$ & $0.754 \pm 0.005$ & 1600 & $1.455 \pm 0.224$ & $0.168 \pm 0.004$ \\
\hline 200 & $1.822 \pm 0.019$ & $1.146 \pm 0.016$ & $0.849 \pm 0.039$ & 1800 & $1.591 \pm 0.002$ & $0.215 \pm 0.009$ \\
\hline 240 & $2.221=0.066$ & $1.444 \pm 0.073$ & $1.143 \pm 0.073$ & 2000 & $1.780 \pm 0.015$ & $0.258 \pm 0.005$ \\
\hline
\end{tabular}

TABLE 3. THE PERCENTAGE INHIBITION OF SUPEROXIDE ANION RADICAL OF DIFFERENT CONCENTRATIONS OF COMPOUNDS 1-4 AND VC

\begin{tabular}{ccccccc}
\hline $\begin{array}{c}\text { Concentration } \\
(\mu \mathrm{g} / \mathrm{ml})\end{array}$ & 1 & 2 & 3 & 4 & $\begin{array}{c}\text { Concentration } \\
(\mu \mathrm{g} / \mathrm{ml})\end{array}$ & VC \\
\hline 36 & $37.97 \pm 0.913$ & $34.47 \pm 1.186$ & $37.94 \pm 0.892$ & $6.27 \pm 0.331$ & 2 & $10.42 \pm 0.327$ \\
44 & $49.61 \pm 1.013$ & $43.36 \pm 0.888$ & $46.29 \pm 1.377$ & $10.09 \pm 0.542$ & 4 & $21.49 \pm 0.483$ \\
52 & $62.87 \pm 1.012$ & $51.33 \pm 1.043$ & $51.52 \pm 0.628$ & $15.83 \pm 1.087$ & 6 & $41.31 \pm 0.688$ \\
60 & $76.51 \pm 1.200$ & $63.40 \pm 0.399$ & $65.69 \pm 1.392$ & $20.46 \pm 1.232$ & 8 & $58.09 \pm 0.991$ \\
68 & $85.11 \pm 1.005$ & $74.50 \pm 1.165$ & $76.57 \pm 1.364$ & $25.49 \pm 1.135$ & 10 & $75.02 \pm 1.003$ \\
76 & $99.27 \pm 1.451$ & $85.02 \pm 1.644$ & $87.67 \pm 1.186$ & $32.92 \pm 0.956$ & 12 & $87.74 \pm 1.290$ \\
\hline
\end{tabular}

TABLE 4. IC S0 $_{50}$ VALUES OF COMPOUNDS 1-4 AND VC $(\mu \mathrm{G} / \mathrm{ML})$ 


\begin{tabular}{cccccc}
\hline Assay & VC & 1 & 2 & 3 & 4 \\
\hline RSA $\left(\mathrm{O}_{2}^{-} \cdot\right)$ & $7.17 \pm 0.044$ & $44.06 \pm 0.114$ & $50.03 \pm 0.466$ & $48.28 \pm 0.162$ & $108.21 \pm 0.614$ \\
$\operatorname{RSA}(\mathrm{ABTS})$ & $38.52 \pm 0.118$ & $93.59 \pm 0.359$ & $175.84 \pm 1.064$ & $144.5 \pm 0.091$ & $192.84 \pm 1.201$ \\
$\mathrm{RSA}(\mathrm{DPPH})$ & $1.45 \pm 0.008$ & $2.51 \pm 0.018$ & $20.87 \pm 0.235$ & $3.69 \pm 0.024$ & $61.07 \pm 0.373$ \\
$\mathrm{EC}_{50}$ & & & & & \\
(Reducingpower) & $19.25 \pm 0.723$ & $105.67 \pm 0.619$ & $714.37 \pm 11.170$ & $119.35 \pm 1.496$ & $3175.33 \pm 22.805$ \\
\hline
\end{tabular}

The results from table 2 and table 3 showed that these compounds had antioxidant activity in a concentration-dependent manner. The $\mathrm{ABTS}^{+}$radicals scavenging activity of compounds $\mathbf{1}, \mathbf{2}, \mathbf{3}$ and $\mathbf{4}$ were respective with the $\mathrm{IC}_{50}$ values of $93.59 \pm 0.359$, $175.84 \pm 1.064,144.5 \pm 0.091$ and $192.84 \pm 1.20 \mu \mathrm{g} / \mathrm{mL}$ (Table 4). Among which compound 1 have higher antioxidant activity than other three compounds. The $\mathrm{IC}_{50}$ of compounds $\mathbf{1}$ and $\mathbf{3}$ on DPPH radical scavenging $(2.51 \pm 0.018$ and $3.69 \pm 0.024)$ was very close, and lower than that of compounds 3 and $4(20.87 \pm 0.235$ and61.07 \pm 0.373). In addition, the $\mathrm{IC}_{50}$ of compounds $\mathbf{1}, \mathbf{2}$ and $\mathbf{3}$ on superoxide anion radical Scavenging was approximative (44.06 $\pm 0.114,50.03 \pm 0.466$ and $48.28 \pm 0.162)$, and far less than that of compound $4(108.21 \pm 0.614)$, showing stronger antioxidant activity. The reducing capacity of a compound may serve as a significant indicator of its potential antioxidant activity. The reducing power assay measures the electron-donating ability of antioxidants using the potassium ferricyanide reduction method. In the test, compounds 2, 4 didn't show antioxidant activity when their concentrations wasn't higher than $240 \mu \mathrm{g} / \mathrm{mL}$; However, compounds 1, 3 showed different levels of antioxidant activity at these concentrations. Compounds $\mathbf{1}$ and $\mathbf{3}$ had higher activity than other two compounds. The results obtained from this study showed that multiple in vitro methods targeting different radical species and reducing power were important for testing antioxidant potential of compounds. Employment of more than one test method gave a better estimate of comparative antioxidant potential of these compounds. According to these results, the order of antioxidant activity of these flavonoids is as follows: $\mathbf{1}>\mathbf{3}>\mathbf{2}>\mathbf{4}$.

\section{CONCLUSION}

In conclusion, the four compounds from the pulps of $E$. angustifolia exhibited different levels of antioxidant activity in all tested models. Considering related reports [6], the flavonoid might be responsible for antioxidant activity of pulp of E. angustifolia. Further investigation should be focused on the isolation of more individual compounds to complement and confirm the results of the antioxidant action of flavonoids and their glycosides.

\section{ACKNOWLEDGMENT}

This study was financially supported by Coordinated Development of Disciplines Fund of Lanzhou University of Technology.

\section{REFERENCES}

[1] Editorial committee of Chinese flora. Chinese flora. In: Huang cj, editor. Rutaceae. Second Fascicule. Beijing: Science Press, 1983, pp 1-60.

[2] Editorial committee of Jiangsu New Medical College. Traditional Chinese medicine Dictionary. Shanghai: Shanghai Science Technology Press, 1997, pp. 1162.

[3] Ding, Y. S., Wang Z., Ma, R. L., Feng, G. L., Xu S. Z., Lu, F. L., Tang, M.E., \& Zheng, R. H, "Anti-fatigue Effect and Mechanism of Polysaccharides from Eleagnus angustifolius L," Food Science, vol. 31, Nov. 2011, pp. 255-257.

[4] Maildan, M., Aziguli, W., \& Gulixian H. "The anti-inflammatory, analgesic, antipyretic and antibacterial activities of aqueous extract from Eleagnus angustifoliu.," Journal of Northwest Pharmaceutical, vol. 26, Jan. 2011, 43-46.

[5] Feng, T., Yan, T. T., Yan G. r., \& Peng, L. X. "Free Radical Scavenge Capacity of Elaeagnus angustifolia Extracts," Medicinal Plant, vol.1, Feb.2010, pp. 24-26.

[6] Si, C. L., Xu, J., Wu, L., Hui, L. F., Liu, P. T., \& Liu, Z. “Antioxidant flavonoids from bark of Elaeagnus angustifolia," Plant Medical, vol. 75, Sep. 2009, pp. 943-944.

[7] Wang, X.R., \& Wei, S. N. "Study on biology and chemical constituents of Elaeagnus Angustifolia," Shannxi agriculture Science, vol. 6, 2010, pp. 47-50.

[8] Liu, Q., \& Yao, H. Y. “Antioxidant activities of barley seeds extracts," Food Chemistry, vol. 102, Mar. 2007, pp. 732-737.

[9] Re, R., Pellegrini, N., Pannala, A., Yang, M., \& Rice-Evans, C. "Antioxidant activity applying an improved ABTS radical cation decolorization assay," Free Radical Biology and Medicine, vol. 26, Sep. 1999, pp. 1231-1237.

[10] Chen, Y., Wang, M. F., Rosen, R. T., \& Ho, C. T. "2,2-Diphenyl-1-picrylhydrazyl Radical-Scavenging Active Components from Polygonum multiflorum Thunb," Journal of Agricultural and Food Chemistry, vol. 47, Jun. 1999, pp.2226 -2228.

[11] Zhang. T., Li, Y. H., Miao, M., \& Jiang, B. "Purification and characterisation of a new antioxidant peptide from chickpea (Cicer arietium L.) protein hydrolysate," Food Chemistry, vol. 128, 2011, pp. 28-33.

[12] Kosanić, M., Ranković, B., \& Vukojević, J. “Antioxidant properties of some lichen species,” Journal of Food Science and Technology-mysore, vol. 48, May. 2011, pp. 584-590.

[13] Jaramilio, K., Dawid, C., Hofmann, T., Fujimoto, Y., \& Osorio, C. (2011). "Identification of Antioxidative Flavonols and Anthocyanins in Sicana odorifera Fruit Peel," Journal of Agricultural and Food Chemistry, vol. 59, Mar. 2011, pp. 975-983.

[14] Park, S. H., Kim, H., \& Rhyu, D. Y., “ Flavonoids from the stems of eastern picklypear Opuntia humifusa, Cactaceae," Journal of Applied. Biological Chemistry, vol. 50, Apr. 2007, 254-258.

[15] Aquino, R., Morelli, S., Tomaino, A., \& Pellegrino, M. (2002). "Antioxidant and photoprotective activity of a crude extract of Culcitium reflexum H.B.K. leaves and their major flavonoids," Journal of Ethnopharmacology, vol. 79, Feb. 2002, 183-191. 